\author{
Adam Wojtczak \\ Uniwersytet im. Adama Mickiewicza w Poznaniu \\ ORCID: 0000-0001-6431-2116
}

\title{
Teologiczna wymowa maryjnego tytułu „Pociecha migrantów" według papieża Franciszka
}

\begin{abstract}
Abstrakt: Zjawisko migracji przybrało współcześnie formę globalną. Migranci poszukują nie tylko pracy i lepszych warunków życia, ale także pokoju i bezpieczeństwa. Ich losy są wyzwaniem dla Kościoła, który w ich przyjmowaniu, chronieniu, promowaniu i integrowaniu jest inspirowany przez Maryję. Stanowi Ona także ostoję dla samych migrantów. Dlatego papież Franciszek przyznał Jej w 2020 roku tytuł Solacium migrantium (Pociecha migrantów), który polecił włączyć do Litanii loretańskiej. Celem niniejszego artykułu jest przedstawienie teologicznej wymowy tego tytułu w ujęciu papieża z Argentyny. Postawione zadanie tym bardziej interesujące i pożyteczne, że Franciszek nie odpowiada ani wprost, ani wyczerpująco na pytania: Dlaczego Maryja jest szczególnie bliska migrantom? Jakie predyspozycje Matki Boga umożliwiają Jej niesienie pociechy migrantom? W jaki konkretnie sposób to czyni? Artykuł podąża śladami papieskich wypowiedzi o różnej proweniencji, aby wyłuskać z nich myśli, które składają się na rozumienie tytułu "Pociecha migrantów" przez papieża Franciszka.
\end{abstract}

Słowa kluczowe: Maryja, migracja, Kościół, mariologia, papież Franciszek, "Pociecha migrantów"

\section{Wprowadzenie}

Z jawisko migracji towarzyszy dziejom ludzkości od ich początków. Jest wyrazem pragnienia szczęścia, właściwego każdej istocie ludzkiej, którego należy poszukiwać i do którego należy dążyć. W XXI w. migrowanie jawi się jednakże jako „znak czasów”, przybiera formę globalną. Nie ogranicza się do pewnych regionów, lecz obejmuje wszystkie kontynenty i coraz bardziej nabiera - jak to

1 Franciszek, ,Migranci i uchodźcy”, 4. 
określa Franciszek - „rozmiarów dramatycznej kwestii światowej”2 Migrantami są nie tylko osoby poszukujące godnej pracy i lepszych warunków życia, lecz także zmuszane kataklizmami naturalnymi, prześladowaniami lub skrajnym ubóstwem do opuszczenia swoich domów w nadziei na ratunek i znalezienie pokoju i bezpieczeństwa gdzie indziej. Ich przybycie rodzi często w lokalnych społecznościach strach, podejrzenie i wrogość. Są traktowani jak „ciała obce”, które nie są dość godne, by uczestniczyć jak wszyscy inni w życiu społecznym.

Losy migrantów są wyzwaniem dla Kościoła, prowokacją dla wiary i miłości wierzących. „Na globalizację zjawiska migracji apeluje papież - trzeba zareagować globalizacją miłości i współdziałania, aby stworzyć migrantom bardziej humanitarne warunki"4. Kościół jest matką, której macierzyńska czułość i bliskość wobec migrantów powinna wyrażać się w czterech czasownikach: ,„przyjmować, chronić, promować i integrować"5. Inspiracją dla owych postaw jest Maryja. Spoglądając na Nią, odkrywamy najbardziej czułe oblicze Kościoła i ,zaczynamy wierzyć w rewolucyjną moc czułości i miłości" .

Maryja jest również doniosłą pomocą dla samych migrantów. $\mathrm{Z}$ tego względu Franciszek nadał Jej tytuł Solacium migrantium ${ }^{7}$ i polecił, aby został on włączony do Litanii loretańskiej. Uczyniła to Kongregacja do spraw Kultu Bożego i Dyscypliny Sakramentów dnia 20 czerwca 2020 roku $^{8}$, a Konferencja Episkopatu Polski za-

2 Franciszek, „Nieletni migranci”, 4.

3 Franciszek, Fratelli tutti, 98.

4 Franciszek, „Kościół bez granic”, 5. Por. I. Okafor, „Der Verzweifelte Migrant", 291-292.

5 Franciszek, „Przyjmowanie, chronienie”, 4. „Sądzę, że odmienianie tych czterech czasowników [...] jest dziś obowiązkiem [...] względem braci i sióstr, którzy z różnych powodów są zmuszeni do opuszczenia miejsc swojego pochodzenia - jest to obowiązek sprawiedliwości, cywilizacji i solidarności” (Franciszek, „Przyjmować, chronić”, 21). Por. W. Kućko, „Braterstwo”, 145.

6 Franciszek, Evangelii gaudium, 288. Por. A. Avi Mello, Mit Maria leben, 166-177; Ch. Schönborn, „Maria - Herz der Theologie”, 126-133.

7 Franciszek, „Spotkanie z innym”, 5.

8 Kongregacja ds. Kultu Bożego i Dyscypliny Sakramentów, „Litterae circulares". 
decydowała 28 sierpnia tego samego roku, że polska wersja tytułu będzie brzmiała „Pociecha migrantów”, choć jej Komisja do spraw Kultu Bożego i Dyscypliny Sakramentów rekomendowała określenie „Pomoc migrantów”10.

W związku z tym ciekawe i pożyteczne jest przybliżenie teologicznego znaczenia nowo nadanego tytułu w ujęciu papieża Franciszka, tym bardziej, że nikt się tego jeszcze nie podjął. Papież nie przedkłada wprost i wyczerpującego rozumienia tytułu. Dlatego w kolejnych paragrafach podążę śladami jego wypowiedzi o różnej proweniencji, aby wydobyć z nich refleksje, które składają się na papieską interpretację. W pierwszej kolejności ukażę, czym uzasadnia on więź Maryi z migrantami i ich trudnym losem, a następnie, w czym dopatruje się Jej inspiracji i wsparcia dla nich.

\section{Doświadczona migrowaniem}

Powodem wielkości i sercem całej historii Maryi jest wiara ${ }^{11}$. W niej wypowiedziała Ona swoje fiat: ,niech mi się stanie według twego słowa!” (Łk 1,38). „To było - wyjaśnia papież - coś innego niż bierna albo zrezygnowana akceptacja. [...] Było to «tak» osoby, która chce się zaangażować i zaryzykować, która chce postawić wszystko na jedną kartę, bez innych gwarancji, aniżeli pewność, że niesie obietnicę. [...] Maryja niewątpliwie miała przed sobą trudną misję, ale trudności nie były powodem, aby powiedzieć «nie»»" ${ }^{2}$. „Tak” naznaczyło

9 Konferencja Episkopatu Polski, „Biskupi zatwierdzili brzmienie”.

10 „Słowo «solacium» można tłumaczyć na wiele sposobów jako «pociecha, ulga, pomoc, ratunek, ucieczka», ale ze względu na to, że wezwanie ma się znaleźć między już istniejącymi «Ucieczko grzesznych» i «Pocieszycielko strapionych», dlatego słowa «ucieczka» $\mathrm{i}$ «pocieszenie» jako już zajęte nie powinny być brane pod uwagę, pozostają zatem «ulga, pomoc, ratunek». Obecnie wydaje się, że z tych trzech najlepiej brzmi «Pomocy migrantów». Co do wyrażenia «migrantes», posiada ono zasadniczo trzy znaczenia: 1. ci, którzy wędrują (także w poszukiwaniu lepszego losu, czyli migranci we współczesnym rozumieniu), 2. ci, którzy się wyprowadzają, 3. przesiedleni; z tych trzech znaczeń najlepiej w całość komponuje się to pierwsze" (Komisja ds. Kultu Bożego i Dyscypliny Sakramentów Konferencji Episkopatu Polski, „Komunikat”).

11 Por. Franciszek, „Wielka wiara Maryi”, 56.

12 Franciszek, „Potrzeba odwagi”, 26-27. 
Jej drogę macierzyństwa, było ufnym otwarciem się na przyszłość, nie dało Jej przywilejów ani wyróżnień. Przeciwnie - życie Maryi nie było łatwe. Prócz chwil radosnych, przeżyła wiele kłopotliwych i bolesnych wydarzeń życiowych. W ich obliczu Jej odpowiedź wiary pociągała za sobą swoisty trud serca. Maryja przeżyła niejedną noc wiary. Jej osoba „nosi znamiona postaci dramatu” ${ }^{\text {13 }}$ Przebywanie z Jezusem nie było magicznym rozwiązaniem problemów. Szła za Synem ,wąską drogą krzyża"14, odczuwając wokół obojętność, odrzucenie, niekiedy pogardę. Jej droga życia była zbliżona do tej, jaką podążają migranci.

Bezpośrednio po scenie zwiastowania rozpoczęła się dla Maryi droga krzyżowa, na której dała się prowadzić Duchowi Świętemu ${ }^{15}$. Łukasz ewangelista notuje: „Odszedł od Niej anioł” $(1,38)$. „Odszedł - komentuje Franciszek - to mocne słowo. Anioł zostawił [Ją] samą w trudnej sytuacji. Wiedziała, że w szczególny sposób zostanie Matką Boga. Anioł Jej to wyjaśnił, lecz nie wyjaśnił tego innym, tylko Jej. A problemy zaczęły się od razu: pomyślmy o sytuacji nieuregulowanej według prawa, o udręce św. Józefa, [...] o tym, co powiedzą ludzie"16. Józef chciał zwolnić Maryję ze zobowiązania do zamążpójścia, wziąć na siebie winę, był bowiem człowiekiem sprawiedliwym. Kierowany delikatnością zamierzał Ją opuścić w taki sposób, aby Jej nie skrzywdzić, nie narazić na zniesławienie w oczach ludzi. Dopiero gdy anioł wyjawił mu prawdę, okazał swe posłuszeństwo: „wziął swoją Małżonkę do siebie” (Mt 1,25) ${ }^{17}$.

Kiedy zbliżał się dla Maryi czas rozwiązania, była zmuszona wraz z Józefem udać cię do Betlejem, ponieważ Cezar August zarządził spis ludności w całym państwie. Była to Jej druga podróż, bo pierwsza zawiodła Ją nieco wcześniej do Ain-Karim, domu Elżbiety i Zachariasza. A zatem Jej dziecko nie mogło narodzić się w domu rodzinnym w Nazarecie. Doświadczenie wydania go na świat przeżywała w warunkach dotkliwego ubóstwa. „Nie było dla nich miejsca w gospodzie”

13 Franciszek, „Maryja stała”, 29.

14 Franciszek, ,Jak Maryja”, 19.

15 Franciszek, Evangelii gaudium, 287.

16 Franciszek, „Wszystko może”, 27.

17 Por. Franciszek, M. Pozza, Ave Maria, 81. 
(Łk 2,7). Oznacza to - tłumaczy papież - że nie mieli domu ani mieszkania, w którym mogliby przyjąć swoje dziecko. Ani bliskiej rodziny, byli sami. Jedynym miejscem, jakie znaleźli, była grota dla zwierzą ${ }^{18}$. Matka była zmuszona złożyć nowo narodzonego Syna w żłobie, w prowizorycznej kołysce, która nie odpowiadała godności „Syna Najwyższego” (Łk 1,32). Jej macierzyństwo od początku realizowało się pod znakiem ludzkiej obojętności, a nawet odrzucenia ${ }^{19}$.

Później spotykamy Maryję i Józefa w świątyni jerozolimskiej, do której przybyli, żeby - zgodnie z Prawem Mojżesza - ofiarować swojego pierworodnego Syna Bogu. Zdumieli się na słowa starca Symeona i prorokini Anny, którzy w Dzieciątku Jezus dostrzegli na własne oczy zbawienie dokonane przez Boga, którego od dawna wyczekiwali. Symeon wziął Je w objęcia i błogosławił Pana, mówiąc: „«Teraz o Władco pozwól odejść słudze Twemu w pokoju [...]. Bo moje oczy ujrzały Twoje zbawienie, któreś przygotował wobec wszystkich narodów: światło na oświecenie pogan i chwałe ludu Twego, Izraela»" (Łk 2,29-32) ${ }^{20}$. Z tą radosną nowiną pojawiła się jednocześnie zapowiedź, że Maryja będzie miała udział w losie Syna: „ «Oto Ten przeznaczony jest na upadek i na powstanie wielu w Izraelu, i na znak, któremu sprzeciwiać się będą. A Twoją duszę miecz przeniknie, aby na jaw wyszły zamysły serc wielu»" (Łk 2,34-35). Te tajemnicze słowa zapowiedziały naznaczoną cierpieniem przyszłość Mesjasza i Matkę złączoną z bolesnym przeznaczeniem Syna. Przyjęła je w milczeniu. Już wówczas zdała sobie sprawę, że „misja i sama tożsamość Jezusa przewyższają Jej macierzyństwo"21.

Niemal każdego dnia spełniało się w życiu Maryi proroctwo Symeona. Dlatego tak wiele motywów nawiązujących do cierpienia Jezusa spotykamy już w Ewangelii Dzieciństwa. Izrael od początku nie chciał przyjąć Mesjasza. Herod chciał Go zabić. Jeruzalem Go odepchnęło (por. Mt 2,1-15). Józef, by ratować Dziecię od śmierci, ucieka z Nim i Jego Matką do Egiptu. Musieli udać się na wygnanie, doświadczyć tragicznej kondycji uchodźców, naznaczonej lękiem,

\footnotetext{
18 Por. Franciszek, „Z Maryją”, 29.

19 Por. Franciszek, „Migranci i uchodźcy”, 6.

20 Por. Franciszek, ,Ruch i zdumienie”, 33.

21 Franciszek, „Ci, którzy potrafią”, 18.
} 
niepewnościami i trudnościami ${ }^{22}$. „Tam - opisuje Franciszek - nie tylko nie mieli miejsca ani rodziny, ale nawet ich życie było zagrożone. Musieli wyruszyć w drogę ku obcej ziemi. Byli migrantami i prześladowanymi z powodu pychy i zachłanności [Heroda]"23. Znaleźli się w gromadzie ludzi ostatnich, marginalizowanych przez społeczeństwo.

Po śmierci Heroda dla rodziny wygnańców pojawiła się nadzieja. Wezwanie anioła sprawiło, że Jezus, Maryja i Józef mogli powrócić do swego kraju i zamieszkać w Nazarecie. Tak prowincjonalna wioska stała się miejscem ich życia ukrytego. Maryja żyła wiarą - uczy papież - „W prostocie tysiąca codziennych zajęć i trosk każdej mamy, takich jak przygotowywanie posiłków, dbanie o odzież, o dom... Ta właśnie normalna egzystencja Maryi była gruntem, na którym rozwinęła się szczególna relacja i głęboki dialog pomiędzy Nią [...] i Jej Synem"24. Matka widziała, jak wzrastał w latach, mądrości i łasce pośród nich, a także wzrastała Jej miłość do Niego i zrozumienie Go. Z Jego nauczycielki stawała się powoli Jego pierwszą uczennicą. Kiedy Jezus miał dwanaście lat, Maryja i Józef udali się z Nim, jak każdego roku, do Jerozolimy na święto Paschy. Gdy rodzice ruszyli w drogę powrotną do Nazaretu, Jezus pozostał w Jerozolimie. Szukali Go trzy dni pośród krewnych i znajomych. Znaleźli Go w świątyni, ,gdzie siedział pomiędzy nauczycielami, przysłuchiwał się im i zadawał pytania (Łk 2,46). Na wyrzut Maryi, wyrażający ich zaniepokojenie i lęk: „Synu, czemuś nam to uczynił? Oto ojciec twój i ja z bólem serca szukaliśmy Ciebie” (w. 48) odpowiedział: „Czemuście Mnie szukali? Czyż nie wiedzieliście, że powinienem być w tym, co należy do mego Ojca?” (w. 49). Tymi słowami zaprosił ich do przekroczenia sfery dostrzegalnej rzeczywistości i otwarcia się na nowe perspektywy związane z Jego przyszłością. Ewangelista Łukasz daje komentarz: „Oni jednak nie zrozumieli tego, co im powiedział” (w. 50). Maryja jednak przeżywała ten epizod: „Chowała wiernie wszystkie te wspomnienia w swoim sercu" (w. 51) ${ }^{25}$. Rozważała

22 Por. Franciszek, ,Jak Jezus Chrystus”, 4. Por. J. Kudasiewicz, Matka Odkupiciela, 93.

23 Franciszek, ,Z Maryją”, 29.

24 Franciszek, „Sekret”, 37.

25 Por. Franciszek, „Potrzebna jest rodzina”, 16. 
wszystkie napotykane wydarzenia i słowa „w świetle Ducha Świętego, aby zrozumieć i wypełnić w praktyce całą wolę Boga"26.

„Tak” Maryi, doskonałe już na początku, stawało się coraz pełniejsze podczas publicznej działalności Jezusa. Choć nie zawsze uczestniczyła w wędrówkach misyjnych Syna, to jednak śledziła przebieg Jego działalności apostolskiej. Spoglądała na nią z uniesieniem, ale również z obawą, gdyż Jezus stawała się „,coraz bardziej owym znakiem sprzeciwu, który przepowiedział Jej Symeon"27. Była z pewnością świadkiem niezrozumienia i wrogości ziomków, którzy wypędzili Go z synagogi, a nawet próbowali zabić, gdy po odczytaniu mesjańskiego proroctwa Izajasza skomentował tekst, odnosząc jego treść do siebie (por. Łk 4,18-30) ${ }^{28}$. Uczestniczyła w Jego dramacie, kiedy czuł się odrzucony przez część swego narodu. Słyszała słowa obelg kierowanych pod Jego adresem: „Jaki jest wielki! - Ależ to nie jest Bóg! - Ten nie, nie jest prawdziwie wierzącym!"229. Znosiła wszystkie cierpienia z wielką godnością, zmierzając z Synem „do Jerozolimy" (Łk 9,51).

Zespolenie Maryi z Jezusem osiągnęło szczyt na Kalwarii w „męczeństwie serca”, „utożsamieniu się z bólem Syna”30. Przeżywała Jego „godzinę” jako własną ,godzinę”. Nie oddaliła się od Niego z bojaźni. „Nikt nie może powiedzieć - kontynuuje myśl papież - która męka w tamtej chwili [...] była bardziej okrutna: czy męka niewinnego człowieka umierającego na krzyżu, czy agonia Matki, towarzyszącej Synowi w ostatnich chwilach Jego życia. Ewangelie [...] opisują obecność Matki prostym słowem «stała» (J 19,25). [...] Nic nie mówią o Jej reakcji: czy płakała, czy nie płakała... nic; ani jednej wzmianki o Jej bólu. [...] Ale mówią tylko: Ona «stała». Stała tam w najgor-

26 Franciszek, ,Sekret”, 37.

27 Franciszek, „Ci, którzy potrafią”, 18. Por. A. Wojtczak, Czułe oblicze Matki, 139.

28 „Z pewnością tamtego dnia w synagodze nazaretańskiej była także Maryja, Matka. Możemy sobie wyobrazić odczucia Jej serca, drobną zapowiedź tego, co będzie cierpiała pod krzyżem, widząc Jezusa, który tam, w synagodze najpierw był podziwiany, a potem prowokowany, znieważany, grożono Mu śmiercią" (Franciszek, „Jedynym przywilejem”, 43).

29 Franciszek, „Kiedy Jezus”, 55.

30 Franciszek, „Sekret”, 38. Por. P. Warchoł, „Maryja”, 225. 
szym momencie, najbardziej okrutnym, i cierpiała razem z Synem"31. Upokarzające cierpienie Jej nie sparaliżowało. Pozostała niezłomna i milcząca. Nie wyparła się Syna, chociaż narażała się na krytykę wobec Niego, gdyż „to było Jej ciało"32.

Obecność Maryi na Kalwarii była nie tylko wyrazem Jej macierzyńskiej miłości, ale nade wszystko aktem głębokiej wiary. W posłuszeństwie wiary przeżywała zbawczą śmierć Jezusa. Pod krzyżem stała w obliczu zupełnego zaprzeczenia obietnicy, jaką otrzymała podczas zwiastowania: Jej Syn będzie wielki i ,będzie panował nad domem Jakuba na wieki” (Łk 1,32-33). Nie zwątpiła jednak. W Jej udręczonym sercu palił się płomień nadziei. Pozostała „niewiastą czujnego oczekiwania [...] na jutro Boga"33, które okazało się dla Niej świtem poranka zmartwychwstania Jezusa. Jej serce napełniło się „radością wiary” ${ }^{34}$. Mogli z niej skorzystać Jego uczniowie. Serce Maryi było dla nich „,́ródłem pokoju, pocieszenia, nadziei, miłosierdzia" 35 .

Ewangelie pokazują, że Maryja przeżyła wiele podróży i wędrówek. Nigdy nie były one dla Niej łatwe, ponieważ były pełne zagrożeń i cierpienia ${ }^{36}$. Wymagały od Niej odwagi i cierpliwości. W obliczu wszystkich trudności i niespodzianek Jej nadzieja nigdy się nie zachwiała. Matka Jezusa zwykła była słuchać Boga i całkowicie ufać Jego woli. Wiara podpowiadała Jej, że Bóg liczy się bardziej, niż Jej własne ,ja"37. Nie stawiała przeszkód, lecz z gotowością Mu zawierzyła. „Wszystkie te sprawy” (Łk 2,19) - a więc nadzieje i niepokoje, radości i smutki - rozpatrywała w swoim sercu z Bogiem. „Niczego nie zatrzymywała dla siebie, niczego nie zamknęła w samotności ani

31 Franciszek, „Maryja stała”, 30.

32 Franciszek, „Pod płaszczem Matki”, 26.

33 Franciszek, „Ci, którzy potrafią”, 18-19. Por. A. Awi Mello, Mit Maria leben, 190-193.

34 Franciszek, „Wiara Maryi”, 5.

35 Franciszek, „Doświadczenie”, 23. Szerzej postawę niezachwianej nadziei Maryi na Kalwarii omawia A. Wojtczak, Czułe oblicze Matki, 143-144.

36 Franciszek przypomina, że chrześcijańska pobożność wspomina o „siedmiu boleściach” Maryi (Por. „Matka Boża Bolesna”, 38).

37 Por. Franciszek, „Wszystko może”, 26. 
nie topiła w goryczy, wszystko zanosiła Bogu"38. Przebywając z Nim w każdej sytuacji, „uczyniła swe życie pięknym”39.

\section{Za przykładem Maryi}

Papież Franciszek wskazuje wielokrotnie, że Maryja jest naszą siostrą w wierze. Całe Jej życie było niestrudzonym poruszaniem się, wędrowaniem. Była Ona obca w Betlejem i Egipcie, z dala od rodziny i przyjaciół. Jednakże - doświadczona koniecznością przemieszczania się i prześladowaniami - potrafiła w duchu wiary zaradzać trudom niedostatków, bezradności i osamotnienia. Migranci mogą utożsamiać się z wieloma sytuacjami Jej życia. Mogą opowiadać Jej o swoich realiach, gdyż Ona je rozumie. Więcej, jest Ona dla nich nauczycielką przezwyciężania napotykanych ograniczeń i kłopotów. Dlatego warto wejść do „,szkoły Maryi”40, by oświecała Ona ich „myśli i działania"41 - zwłaszcza wtedy, kiedy w chwilach smutku i udręce prześladowań rozglądają się wokoło siebie, aby znaleźć kogoś, kto naprawdę zrozumienie ich opuszczenie, nauczy pokonywać wyboiste i strome zakręty życia, a także roznieci w nich poczucie nadziei, która rodzi i otwiera przyszłość, niezależnie od wszelkich okoliczności, które ją przesłaniają lub próbują zgasić.

W pierwszej kolejności migranci potrzebują matczynego spojrzenia Maryi. Papież zachęca ich, aby pozwalali Jej na siebie patrzeć i zarazem prosi Ją, by uczyła ich swojego patrzenia na życie i niedole ${ }^{42}$. Jej oczy potrafią rozświetlać każdą ciemność, pomagają postrzegać siebie jako umiłowane dzieci w wiernym ludzie Bożym oraz miłować się wzajemnie, niezależnie od ograniczeń i nastawienia każdego. Inaczej mówiąc, uczy Ona patrzenia na siebie nawzajem po bratersku, zachęca, aby byli oni prawdziwie braćmi ${ }^{43}$. Ponadto

38 Franciszek, „Przed żłóbkiem”, 18.

39 Franciszek, „Grzech postarza”, 45.

40 Franciszek, „Naszym zadaniem”, 14.

41 Franciszek, „Kościół apeluje”, 24.

42 Por. Franciszek, „Matka Boża”, 20.

43 Por. Franciszek, „Przybyliśmy”, 24. „Chcemy spotkać Jej macierzyńskie spojrzenie, [...] które wyzwala nas z osierocenia, [...] które przypomina, że jesteśmy braćmi: że należę do ciebie, ty należysz do mnie, że jesteśmy z tego samego ciała, 
Solacium migrantium nigdy nie wskazuje na siebie, lecz na Jezusa Chrystusa. Pomaga „odkrywać oblicze swojego Syna we wszystkich braciach i siostrach, zmuszonych do ucieczki ze swojej ziemi z powodu licznych niegodziwości, które jeszcze dzisiaj gnębią nasz świat" ${ }^{44}$. Relacje, które otwierają na braterstwo z innymi, uzdrawiają i czynią migrantów wolnymi, gdyż pozwalają im odkryć w nich samego Boga.

Można przyjąć, że dla Franciszka migrowanie „oznacza poczucie się wezwanymi i pobudzonymi, aby podążć razem, prosząc Pana o łaskę przemieniania dawnych i obecnych uraz i nieufności w nowe szanse jedności; oznacza oderwanie się od naszych pewników i wygód, by wyruszyć na poszukiwanie nowej ziemi, którą Pan chce nam dać"45. Zmuszeni do opuszczenia własnego regionu lub kraju żyją zwykle między wykorzenieniem a integracją. To napięcie niszczy wielu z nich ${ }^{46}$. Dlatego migracja jest dla nich wyzwaniem, by nie obawiać się wymieszania osób i kultur, lecz spotykać się z drugimi. Papież mówi o mistyce ludzkiego spotkania, uczestnictwie w solidarnej karawanie i doświadczeniu braterstwa ${ }^{47}$. Nawołuje do wędrowania razem $^{48}$, wychodzenia poza krzywdy i rany, aby tworzyć komunię ze wszystkimi bez ulegania pokusie izolowania się. Można bowiem „być obok”, ale nie „razem”49, nie przyjąć i zaakceptować drugiego, który podziela mój los migranta. Maryja uczy podążania drogą braterstwa $^{50}$. Jej postawa w scenie nawiedzenia Elżbiety i wesela w Kanie ujawnia, że solidarność rodzi się z umiejętności zrozumienia potrzeb drugich. Aby osiągnąć harmonijne współistnienie kultur i osób, nie wystarczy sama tolerancja, która otwiera drogę do poszanowania

[...] które uczy, że musimy nauczyć się troski o życie w taki sam sposób i z taką samą czułością, z jaką Ona się zatroszczyła: zasiewając nadzieję, przynależność, siejąc braterstwo" (Franciszek, M. Pozza, Ave Maria, 49-50). Por. A. Wojtczak, „Marian Inspirations”, 120-121.

44 Franciszek, „Spotkanie z innym”, 5.

45 Franciszek, „Łaska przemieniania”, 25.

46 Por. Franciszek, „Kościół apeluje”, 23.

47 Por. Franciszek, Evangelii gaudium, 87.

48 Por. Franciszek, „Łaska przemieniania”, 25; W. Kućko, „Braterstwo”, 137.

49 Franciszek, „Trzeba przyjąć”, 31.

50 Por. Franciszek, „Droga braterstwa”, 22. 
różnorodności, ale niezbędna jest kultura spotkania - jedyna, która przezwycięża granice i umożliwia przejście od postawy obronnej, nacechowanej strachem i brakiem zainteresowania, do świata autentycznie braterskiego ${ }^{51}$. Spojrzenie Maryi pozwala patrzeć nie tylko na Nią, ale także patrzeć przez Nią w oblicze wszystkich tych, którzy zjednoczeni w spojrzeniu stają się ludem ${ }^{52}$. Można mówić wówczas o cudzie wzbudzonym przez kulturę spotkania, w której nikt nie jest odrzucony, lecz - przeciwnie - każdy jest niezbędny, posiada przyjacielskie relacje i pragnie uczestniczyć w życiu społeczności, do której przywiodła go migracja ${ }^{53}$.

„Solidarność - czytamy w encyklice Fratelli tutti - wyraża się w sposób konkretny poprzez służbę, która może przybierać wiele różnych form przejmowania odpowiedzialności za innych. Służba «oznacza przeważnie troskę o to, co słabe. [...] Dlatego nigdy nie jest ideologiczna, ponieważ nie służy się ideom, ale służy się osobom»" ${ }^{54}$. Maryję z Nazaretu cechowało „,prawo ekstazy” 55 - przekraczanie siebie, aby nieść macierzyńskie wsparcie bliźniemu. Jej dynamika uczynności, wyruszania ku drugim czyni z Niej wzór chrześcijańskiej służby, która jest w stanie zapoczątkować „rewolucję czułości” ${ }^{56}$. Jedynie czułość - przekonuje Franciszek - może realnie zmienić świat i budować społeczeństwo głęboko ludzkie. Owa rewolucja musi się dokonać zarówno w sercach i umysłach migrantów, jak i nawróceniu pastoralnym Kościoła. Maryja była kobietą wierną i kreatywną, odważną i cierpliwą, kobietą znoszącą wiele rzeczy, dlatego należy spoglądać na Nią jak reagowała w sytuacjach, które wymagały zaradzenia potrzebom ${ }^{57}$. Jej ,„pasja serca"58 ujawniała się w konkretnych czynach i gestach pomocy, bliskości i serdeczności wobec tych, którzy potrzebowali przyjęcia i troski. W ten sposób

\footnotetext{
51 Por. Franciszek, „Kościół bez granic”, 5.

52 Por. M. Borghesi, Jorge Mario Bergoglio, 422.

53 Por. Franciszek, „Umacniajcie kulturę spotkania”, 23.

54 Franciszek, Fratelli tutti, 115.

55 Tamże, 88.

56 Franciszek, Evangelii gaudium, 288. Por. W. Kasper, Papież Franciszek,

57 Por. Franciszek, ,Naszym zadaniem”, 14.

58 Franciszek, „Uczeń Chrystusa”, 53.
} $75-76$. 
pokazuje Ona jak stawiać czoła nędzom i cierpieniom migrantów z poszanowaniem ich kultury ${ }^{59}$. Potrzebują oni współczucia, wzięcia na siebie ich cierpień, stawania się dla nich bliźnimi, aby ich „ukoić, uzdrowić i ocalić" 60 .

Maryja otwiera migrantów także na Boga, ożywia ich pamięć o Nim i pomaga zrozumieć, jak bardzo On ich kocha. Jednocześnie uczy, że Duch Święty kieruje ich „mądrością pamięci” i „,mądrością serca"61. W tym względzie wymowny jest dla papieża z Argentyny kantyk Magnificat. Jest on pełną pamięci modlitwą ludu Bożego, który wędruje w historii. Modlitwą, która uświadamia, że Bóg jest pośród nich ${ }^{62}$, działa jako pierwszy, zagrzewa serca i obejmuje opieką $^{63}$. Jego miłosierdzie jest siłą sprawczą historii - zarówno osobistej, każdego człowieka, jak i całej ludzkości. Jego czuła troska jest jedyną siłą zdolną podbić serca ludzi ${ }^{64}$. Dlatego migranci nie mogą być więźniami własnych słabości, sił i krótkowzroczności. Powinni - za wzorem Maryi - otworzyć się na łaskę, pozwolić ogarnąć przez Boże miłosierdzie. Wtedy to, co wydaje się niemożliwe, zacznie stawać się rzeczywistością. Stała obecność Bożej łaski, choć nie usunie wszystkich ich pokus, krzyży i niepewności, to jednak doda im otuchy i odwagi ${ }^{65}$. Bóg okaże im wielkość swego miłosierdzia, da siłę i otuchę, żeby mogli podążać naprzód. Będzie zawsze z nimi, bo bardzo ich kocha. Dzięki Jego wsparciu, niezależnie od tego, jak wielka byłaby ich bezsilność i zagubienie, będą mogli z odwagą i bez lęku zaczynać od nowa.

Żeby to wszystko się ziściło, trzeba Bogu całkowicie zawierzyć. Maryja potrafiła $\mathrm{Mu}$ w pokorze zaufać, nawet jeżeli nie wszystko rozumiała. Nie protestowała ani złorzeczyła, kiedy życie pokazywało Jej swoje wrogie oblicze. Nie zapominała o związku między nadzieją i słuchaniem słowa Bożego. Nie pozostawiała życia na pastwę lęku

\footnotetext{
59 Por. Franciszek, „Solidarność”, 39.

60 Por. Franciszek, ,Nie chodzi tylko o migrantów”, 5.

61 Franciszek, „Duch Święty”, 22.

62 Por. Franciszek, „Rewolucja czułości”, 25; P. Warchoł, „Maria”, 221.

63 Por. Franciszek, „Pamięć o Bogu”, 43.

64 Por. Franciszek, „Z proroczą odwagą”, 22.

65 Por. Franciszek, „Największą przeszkodą”, 7.
} 
czy zniechęcenia, lecz czyniła ze wszystkiego dialog z Bogiem $^{66}$. Swą postawą uczy Ona migrantów złożenia pełnej ufności w Bogu. Ta ufność musi być zawsze w ich sercach ${ }^{67}$ - i to na pierwszym miejscu - a potem dopiero jest przestrzeń na problemy. „To mądra postawa - konkluduje Franciszek - Nie trzeba żyć, uzależniając się od problemów - gdyż kiedy skończy się jeden, pojawi się inny! - ale ufając Bogu i zdając się na Niego każdego dnia: oto ja! «Oto ja»! jest słowem, «oto ja» jest modlitwą"68. Zupełne postawienie na Boga pomaga z odwagą, bez uników i złudzeń, pokonywać zniesławienia oraz agresję, zaczynać od nowa w sytuacjach, w których wydaje się, że wszystko jest stracone i nie ma wyjścia. Maryja podpowiada ustawicznie sercu uchodźców: „«Wstań! Patrz przed siebie, patrz na horyzont»"69. „Bóg nas zawsze zadziwia, niszczy nasze schematy, burzy nasze plany, mówi: «zaufaj Mi, nie lękaj się, pozwól, bym cię zadziwił, wyjdź poza samego siebie i chodź za Mną!"’70.

Z ufnego zdania się na Boga rodzi się radość, której chrześcijaninowi nic ani nikt nie może odebrać. Potwierdza to w pełni Maryja, która czuła się przez Niego umiłowana i przyjęta. Dlatego w hymnie Magnificat wyśpiewała: ,raduje się duch mój w Bogu, moim Zbawcy, [...] gdyż wielkie rzeczy uczynił mi Wszechmocny" (Łk 1,49). Była radosna, gdyż we wszystkim zaufała Panu. Uświadamia tym samym, że może On czynić cuda również w życiu migrantów, jeżeli otworzą się na Niego i swoją nadzieję złożą w Nim, a nie w świecie ${ }^{71}$. On jest ich Ojcem i siłą. Trzeba umieć dziękować i wielbić Go za wszystko, co dla nich czyni. „Tylko ten - uczy papież - kto potrafi dziękować, doświadcza pełni radości"'72. Wynika ona nie z braku problemów, których w migrowaniu nigdy nie brakuje, ale z doświadczenia obecności Boga. Jest On wielki. Wielbić Go - wyjaśnia papież - dosłownie

66 Por. Franciszek, „Przed żłóbkiem”, 19.

67 Por. Franciszek, „Migranci i uchodźcy”, 6.

68 Franciszek, ,Wszystko może”, 27.

69 Franciszek, „Maryja stała”, 30. Por. A. Wojtczak, „Marian Inspirations”, 125.

70 Franciszek, „Ile razy mówimy”, 7.

71 Por. Franciszek, „Umacniajcie kulturę spotkania”, 23; A. Wojtczak, Czułe oblicze Matki, 207.

72 Franciszek, „Czy umiemy mówić dziękuję?”, 6. 
znaczy „,czynić wielkim”, ,powiększać”73. Migranci nie mogą pozwolić, aby przytłoczyły ich trudności i pokonały lęki. Należy stawiać „Boga jako pierwsza wielkość w życiu”74. Ich radość, podobnie jak w przypadku Maryi, rodzi się z Jego obecności i bliskości. Mali są „Jego słabością z miłości”75. Wierna miłość Boga jest niewyczerpana. „Nie traćcie ufności i nadziei!” - apeluje Franciszek do migrantów i zachęca ich: „Pomyślcie o Świętej Rodzinie na uchodźctwie w Egipcie: tak jak w matczynym sercu Maryi Dziewicy [...] była ufność, że Bóg nigdy nie opuszcza, tak niech wam nie zabraknie podobnej ufności w Panu"76. Maryja jest dla nich nie tylko Matką nadziei, ale stanowi również rzetelne świadectwo nadziei. Pośród mroków męki i śmierci swego Syna wciąż miała nadzieję na Jego zmartwychwstanie, na zwycięstwo miłości Boga. Poprzez to uczy ich ,cnoty czekania, nawet wtedy, kiedy wszystko wydaje się pozbawione sensu" "77. Jej przejawem są „oczekiwania co do przyszłości, chęć posiadania przyjacielskich relacji, pragnienie uczestniczenia w życiu społeczności, która ich przyjmuje, również dzięki uczeniu się języka, możliwość podjęcia pracy i kształcenia najmłodszych. [...] Mają [oni] nadzieję na powrót stopniowo do normalnego życia, w oczekiwaniu na to, że radość i miłość na nowo zagoszczą w ich życiu"78. Także maryjne Magnificat jest hymnem wędrującego ludu Bożego, wszystkich tych, którzy pokładają nadzieję w Bogu, w mocy Jego miłosierdzia. Powinien się on rozlegać szczególnie żarliwie tam, gdzie migranci doznają niepowodzeń i osamotnienia. Przypomina im, że tam, gdzie jest krzyż, jest także nadzieja. Maryja razem z nimi śpiewa Magnificat nadziei ${ }^{79}$.

73 Franciszek, ,Jedna z nas”, 24.

74 Tamże.

75 Tamże.

76 Franciszek, „Kościół bez granic”, 5. „Nie pozwólcie ukraść sobie nadziei i radości życia, które wypływają z doświadczenia miłosierdzia Boga objawiającego się w osobach, które spotykacie na waszych drogach!” (Franciszek, „Kiedy milczenie", 12).

77 Franciszek, „Maryja stała”, 30. Por. P. Warchoł, „Maryja”, 232.

78 Franciszek, „Kościół apeluje”, 23.

79 Por. Franciszek, „Magnificat”, 45; A. Awi Mello, Mit Maria leben, 192. 


\section{Pod opiekuńczym płaszczem Matki}

Migranci i uchodźcy znajdują w Maryi nie tylko przykład radzenia sobie z napotykanymi trudnościami i lękami, ale też czułą i troskliwą Matkę. Dlatego Franciszek nazywa Ją „Matką migrantów i uchodźców" ". Gromadzi ich Ona pod osłoną swojego opiekuńczego płaszcza ${ }^{81}$. Mogą się go uchwycić i tak jak dziecko, kiedy się boi, powiedzieć do Niej „Matko, Mamo"82. Ona nigdy nie zostawia ich samych. W Evangelii gaudium papież Franciszek przytacza słowa Maryi, które Ona sama wypowiada dzisiaj do migrantów tak, jak niegdyś wypowiedziała je do świętego Juana Diego: „Niech się nie trwoży twoje serce [...]. Czyż nie jestem tutaj ja, która jest twoją Matką?" 83 Choć raz na zawsze weszła do chwały nieba, nie znaczy to, że jest daleko. Jest z nimi i otacza czułą opieką.

Można przyjąć - zdaniem papieża - że Maryja niesie migrantom pociechę na trzy sposoby: patrzy na nich, bierze w objęcia i prowadzi za rękę ${ }^{84}$. Pierwszy z nich, macierzyńskie spoglądanie ze świętego obrazu, figury lub medalika, oznacza Jej obecność i towarzyszenie im w wędrowaniu, zwłaszcza wtedy, kiedy są zmęczeni, zniechęceni i przygnieceni problemami. Jej obecność jest dyskretna i milcząca. „Tam gdzie jest matka, tam jest czułość”85, a także zawsze „smak domu" $"$. Nie są oni sierotami. Jej matczyne spojrzenie uwalnia ich od duchowego sieroctwa. Oczy Niepokalanej Matki, które odbijają piękno i czułość Boga, ,potrafią rozświetlać każdą ciemność, rozpalając wszędzie nadzieję"87; zachęcają do tworzenia więzi międzyludzkich i troszczenia się o siebie nawzajem; przypominają, że dla wiary istotna jest czułość, która stawia tamę letniości. Matka, która niegdyś umiała strzec życia i misji swego Syna, jest obecna u boku migrantów, od których ucieka cały świat, którzy są uciskani

\footnotetext{
${ }^{80}$ Franciszek, „Kiedy milczenie”, 12.

81 Por. Franciszek, ,Misericordia et misera”, 12.

82 Franciszek, „Musiałem tutaj przybyć”, 21.

83 Franciszek, Evangelii gaudium, 286.

${ }^{84}$ Por. Franciszek, „Matka Boża”, 20.

85 Franciszek, „Jak w Efezie”, 14. Por. L. Vantinni, „Stabat Mater”, 332.

86 Franciszek, „Tam gdzie jest matka”, 24.

87 Franciszek, „Matka Boża”, 20.
} 
i spychani na margines społeczeństwa ${ }^{88}$. Czuwa nad nimi na drodze nadziei ku lepszemu jutru ${ }^{89}$.

Po spojrzeniu - kontynuuje wątek Franciszek - w grę wchodzi serce. W Matce migranci dostrzegają ,kobiece serce, bijące jak serce Boga, serce bijące dla wszystkich, bez różnicy"90. Potrzebują serca Matki, które potrafi zachowywać czułość Boga i wsłuchiwać się w bicie ich serca. Jej wszystko leży na sercu. Obejmuje nim wydarzenia pomyślne i niepomyślne. Jest dla migrantów Matką pocieszenia i czułości, „lekarstwem na samotność i rozbicie”, , które nigdy nie zawodzi. Swym płaszczem ociera ich łzy i daje pewność, że nie są one próżne, ale milczącą modlitwą, która wznosi się do nieba. Dźwiga z nimi krzyże, nie pozwalając, by przygniotły ich własne boleści. Poczucie, że są w Jej macierzyńskich ramionach, pod Jej osłoną i opieką, wzbudza w nich radość i pokój. Wszystko to czyni Maryja w swoim typowo matczynym stylu: łagodnym i zarazem odważnym, nigdy nie narzucającym się i zawsze wytrwałym w dobru, cierpliwym wobec zła i zabiegającym o serdeczność. „Mocą Zmartwychwstałego - czytamy w encyklice Fratelli tutti - pragnie zrodzić nowy świat, w którym wszyscy bylibyśmy braćmi, w którym byłoby miejsce dla każdego odrzuconego z naszych społeczeństw, w którym jaśniałyby sprawiedliwość i pokój"92.

Przy wielu okazjach papież postuluje, aby migranci pielęgnowali zażyłą relację z Maryją i zawierzali Jej swe utrapienia i obawy. „Dawni mnisi rosyjscy, mistycy - uzasadnia - mawiali, że w czasach zawieruch duchowych trzeba schronić się pod płaszczem Świętej Bożej Rodzicielki”" ", „W Salve Regina nazywamy Ją «naszym życiem»; wydaje się to przesadą, gdyż Chrystus jest życiem (por. J 14,6), ale Maryja jest tak z Nim zjednoczona i tak bliska nam, że nie ma nic lepszego, niż złożenie życia w Jej ręce i uznanie Jej za nasze «życie, słodycz i nadziejęı" "94. Także papież w zakończeniach przemówień

\footnotetext{
88 Por. Franciszek, Evangelii gaudium, 53.

89 Por. Franciszek, ,Nieletni migranci”, 6.

90 Franciszek, M. Pozza, Ave Maria, 10.

91 Franciszek, „Matka Boża”, 20.

92 Franciszek, Fratelli tutti, 278.

93 Franciszek, „Nie gaśmy nadziei migrantów”, 20.

94 Franciszek, „Matka Boża”, 20.
} 
do migrantów zawierza ich matczynej opiece Maryi: „Zawierzam wszystkich nieletnich emigrantów, ich rodziny, ich wspólnoty [...] opiece Świętej Rodziny z Nazaretu, aby czuwała nad każdym z nich i towarzyszyła im w drodze"95. „Matczynemu wstawiennictwu Najświętszej Maryi powierzamy nadzieje wszystkich migrantów i uchodźców na świecie oraz aspiracje społeczności, które ich przyjmują, abyśmy wszyscy, zgodnie z nadrzędnym Bożym przykazaniem miłosierdzia i miłości bliźniego, uczyli się kochać drugiego, cudzoziemca, jak siebie samego" 96 .

Maryja nigdy nie wskazuje ani nie zatrzymuje ludzi na sobie, ale prowadzi ich do Jezusa. Jako matka pełni bardzo szczególną funkcję: staje pomiędzy swoim Synem Jezusem a nimi w sytuacjach ich niedostatków, w sytuacjach ich nędz i cierpień. Oręduje, tak jak w Kanie, wiedząc, że jako matka może, a nawet powinna przedstawiać Synowi potrzeby ludzi, szczególnie tych najsłabszych i najuboższych ${ }^{97}$. Należą do nich migranci. Maryja podtrzymuje ich ufność, że „Bóg nigdy nie opuszcza"98. Więcej, wprowadza ich w obecność swojego Syna, by zaznali Jego czułej miłości. W Niej i przez Nią Jezus staje się ich bratem i towarzyszem drogi, dzieli z nimi krzyże, nie pozwalając, aby przygniotła ich napotykana obojętność, a nawet wrogość.

Po tym, jak patrzy i bierze w objęcia, Matka ujmuje migrantów za rękę i, jak matki czynią zwykle wobec swoich dzieci, prowadzi ich z miłością w codziennej wędrówce, żeby nie stracili w niej orientacji. Nigdy nie traci ich z oczu. Czuwa nad nimi ${ }^{99}$. Dotyka ich cierpienia, by odrzuceni przez społeczeństwo odczuli Jej macierzyńską bliskość i czułość. Gdy upadają na duchu, swoją ręką podnosi ich i wprowadza na drogę nadziei ${ }^{100}$. Pomaga położyć kres wszelkim sytuacjom ucisku i opuszczenia, które sprawiają, że żyją oni jak ukrzyżowani ${ }^{101}$. To przekonanie wiary pozwala papieżowi Franciszkowi skierować do Niej końcową prośbę: „Weź nas za rękę, Maryjo. Trzymając się Ciebie,

95 Franciszek, „Nieletni migranci”, 6; „Nie chodzi tylko o migrantów”, 6.

96 Franciszek, „Przezwyciężenie lęku”, 45.

97 Por. Franciszek, „Nie gaśmy nadziei migrantów”, 19.

98 Franciszek, „Kościół bez granic”, 5; „Migranci i uchodźcy”, 6.

99 Por. Franciszek, „Nieletni migranci”, 6.

${ }^{100}$ Por. Franciszek, „Bóg przychodzi”, 27.

${ }^{101}$ Por. Franciszek, „Trzeba przyjąć”, 31. 
pokonamy najciaśniejsze zakręty historii. Weź nas za rękę, abyśmy odkryli łączące nas więzy. Zgromadź nas razem pod swoim płaszczem, w czułości prawdziwej miłości, w której wzmacnia się rodzina ludzka: «Pod Twoją obronę uciekamy się, Święta Boża Rodzicielko»" "102.

\section{Podsumowanie}

W interpretacji tytułu „Pociecha migrantów” Franciszek nawiązuje do nauczania Soboru Watykańskiego II, które wskazuje na Maryję jako ,znak [...] pociechy"103. Kontekst, w jakim znajduje się owo określenie pozwala dostrzec jego eschatyczny wymiar. Posoborowi papieże i teolodzy przekraczają tę perspektywę, podkreślając, że Maryja niesie pocieszenie także tym, którzy pielgrzymując po ziemi, doświadczają różnych utrapień życia. Chodzi więc o pociechę doczesną, otrzymywaną w trudnej dla człowieka chwili ${ }^{104}$. W tym samym kierunku zmierza Franciszkowa interpretacja tytułu Solacium migrantium, co jest charakterystyczne dla teologii latynoamerykańskiej ${ }^{105}$. Przyjmuje on, iż Maryja, sama pocieszona przez Boga, źródło wszelkiej pociechy (por. 2 Kor 1,3), jest pociechą dla migrantów w dwojakim znaczeniu. W pierwszym: jest znakiem tego, co ich cieszy, a zatem znakiem sposobu pocieszania. W drugim zaś znaczeniu solacium oznacza otuchę i wsparcie, czyli Maryja jawi się jako znak tego wszystkiego, co przynosi pomoc i nadzieję. Jednocześnie papież promuje chrystocentryczne odczytanie tego maryjnego tytułu i zdawkowo traktuje ideę „Pocieszycielki w Pocieszycielu”, czyli w Duchu Świętym ${ }^{106}$, którą rozwija i upowszechnia współczesna mariologia.

Przedłożone refleksje dowodzą, że papież Bergoglio widzi w Maryi coś więcej niż „Pociechę migrantów” w dosłownym tego słowa znaczeniu. Jego rozumienie solacium przekracza polski odpowiednik: ,pociecha”. Maryja jest dla nich - według niego - nie tylko pociechą, ale również ratunkiem, pomocą i ucieczką. Sama została

${ }^{102}$ Franciszek, „Matka Boża”, 21.

103 Sobór Watykański II, Lumen gentium, 68.

104 Por. J. Kumala, „Maryja znakiem”, 93; A. Wojtczak, „Matka i Królowa”, 109.

105 Por. Ł. Samiec, „Maryja i «preferencyjna opcja na rzecz ubogich»”, 244-245.

${ }^{106}$ Por. J. Kumala, „Maryja znakiem”, 96-98; G.M. Bartosik, „Mediatrix in Spiritu Mediatore”, 504-507. 
doświadczona trudem migrowania. Stąd wie najlepiej, czego potrzebują migranci i jak nieść im pociechę. Czyni to na dwa sposoby. Po pierwsze, w Jej szkole uczą się zaradzania własnym i cudzym niedostatkom, bezradności i osamotnieniu, a także otwierania na czułość Boga, która daje im siłę i otuchę w pokonywaniu dramatycznych sytuacji. Po drugie, migranci odkrywają w Maryi Matkę, która patrzy na nich, bierze w objęcia i prowadzi za rękę. W ten sposób towarzyszy im, strzeże i wspiera w wędrowaniu. Wnosi w nie atmosferę czułej miłości, która pozwala nie tracić nadziei na lepsze jutro.

Solacium migrantium - konkluduje papież - budzi jednocześnie chrześcijańskie sumienia, abyśmy widzieli w migrantach ,nie tylko problem, z którym trzeba się zmierzyć, ale brata i siostrę, których należy przyjąć, szanować i kochać, okazję, którą daje nam Opatrzność, abyśmy wnosili wkład w budowanie [...] bardziej braterskiego świata i bardziej otwartej wspólnoty chrześcijańskiej, w zgodzie z Ewangelią"107. „Migranci [...] pomagają nam odczytywać «znaki czasu». Przez nich Pan wzywa nas do nawrócenia, uwolnienia się od ekskluzywizmu, obojętności i kultury odrzucenia"108.

\title{
The Theological Significance of the Marian Title "Solace of Migrants" According to Pope Francis
}

\begin{abstract}
The phenomenon of migration has become a global issue nowadays. The migrants are not only searching for jobs and better life conditions, but also for peace and security. The fate of the migrants is a challenge for the Church. Mary is an inspiration for Church in the process of their reception, protection, promotion, and integration. Mary is an anchorage for the migrants themselves. That is why, in 2020, Pope Francis granted her the title Solacium migrantium ("Solace of Migrants") and ordered to include it within the Litany of Loreto. The aim of this article is to present the theological significance of the title according to Pope Francis. This task is interesting and useful and the more so, as the Pope does not answer directly and exhaustively the following questions: Why is Mary particularly close to the migrants? Which predispositions allow her to comfort them? In what way, exactly, does she do that? This article follows the Pope's statements of various provenances, in order to extract from them the thoughts which make up his understanding of the title.
\end{abstract}

Keywords: Mary, migration, the Church, Mariology, Pope Francis, "Solace of Migrants"

${ }^{107}$ Franciszek, ,Migranci i uchodźcy”, 6.

${ }^{108}$ Franciszek, „Nie chodzi tylko o migrantów”, 6. 


\section{Bibliografia}

Avi Mello, A., Mit Maria leben. Ein Gespräch mit Papst Franziskus, Leipzig 2016.

Bartosik, G.M., „Mediatrix in Spiritu Mediatore. Pośrednictwo Najświętszej Maryi Panny jako uczestnictwo w pośredniczącej funkcji Ducha Świętego w świetle teologii współczesnej”, Niepokalanów 2006.

Borghesi, M., Jorge Mario Bergoglio. Biografia intelektualna. Dialektyka i mistyka, tłum. D. Chodyniecki, Kraków 2018.

Franciszek, „Kościół apeluje o ochronę godności. Audiencja dla uczestników sesji plenarnej Papieskiej Rady do spraw Duszpasterstwa Migrantów i Podróżujących" (24 maja 2013 r.), L'Osservatore Romano (wyd. pol.) 34 (2013) nr 7, 22-24.

Franciszek, „Migranci i uchodźcy: ku lepszemu światu. Orędzie na Światowy Dzień Migranta i Uchodźcy 2014 roku" (5 sierpnia 2013 r.), L'Osservatore Romano (wyd. pol.) 34 (2013) nr 11, 4-6.

Franciszek, „Magnificat kantykiem nadziei pokornych. Homilia na uroczystość Wniebowzięcia Najświętszej Maryi Panny” (15 sierpnia 2013 r.), L'Osservatore Romano (wyd. pol.) 34 (2013) nr 10, 44-45.

Franciszek, „Przybyliśmy, aby spotkać spojrzenie Maryi. Homilia przed sanktuarium Matki Bożej z Bonarii” (22 września 2013 r.), L'Osservatore Romano (wyd. pol.) 34 (2013) nr 11, 23-24.

Franciszek, „Pamięć o Bogu. Homilia dla katechetów” (29 września 2013 r.), L'Osservatore Romano (wyd. pol.) 34 (2013) nr 11, 43-44.

Franciszek, „Wiara Maryi rozwiązuje «węzeł» grzechu. Katecheza podczas spotkania modlitewnego na placu św. Piotra" (12 października 2013 r.), L'Osservatore Romano (wyd. pol.) 34 (2013) nr 12, 4-5.

Franciszek, „Ile razy mówimy «dziękuję» w rodzinie? Homilia na placu św. Piotra" (13 października 2013 r.), L'Osservatore Romano (wyd. pol.) 34 (2013) nr 12, 7-9.

Franciszek, „Sekret żydowskiej dziewczyny. Katecheza wygłoszona podczas audiencji generalnej" (23 października 2013 r.), L'Osservatore Romano (wyd. pol.) 34 (2013) nr 12, 37-38.

Franciszek, „Ci, którzy potrafią czekać. Homilia podczas nieszporów w rzymskim klasztorze św. Antoniego Opata" (21 listopada 2013 r.), L'Osservatore Romano (wyd. pol.) 34 (2014) nr 1, 18-19.

Franciszek, Adhortacja apostolska Evangelii gaudium (24 listopada 2013 r.), wyd. 2., Kraków 2014.

Franciszek, „Doświadczenie, które trzeba przeżyć razem. Rozważanie przed modlitwą Regina caeli” (21 kwietnia 2014 r.), L’Osservatore Romano (wyd. pol.) 35 (2014) nr 5, 23. 
Franciszek, „Duch Święty nauczycielem życia. Homilia na uroczystość Zesłania Ducha Świętego" (8 czerwca 2014), L'Osservatore Romano (wyd. pol.), 35 (2014) nr 7, 21-22.

Franciszek, „Kościół bez granic matką wszystkich. Orędzie na Światowy Dzień Migranta i Uchodźcy 2015 roku” (3 września 2014 r.), L'Osservatore Romano (wyd. pol.) 35 (2014) nr 10, 4-5.

Franciszek, „Musiałem tutaj przybyć, aby być z wami. Homilia na lotnisku w Tacloban" (17 stycznia 2015 r.), L'Osservatore Romano (wyd. pol.) 36 (2015) nr 2, 20-22.

Franciszek, „Z Maryją paragwajskie kobiety odbudowywały życie wiary i godność swego narodu. Homilia w sanktuarium maryjnym w Caacupé" (11 lipca 2015 r.), L'Osservatore Romano (wyd. pol.) 36 (2015) nr 9, 29-30.

Franciszek, „Wielka wiara Maryi. Rozważanie przed modlitwą Anioł Pański” (15 sierpnia 2015 r.), L'Osservatore Romano (wyd. pol.) 26 (2015) nr 9, 56-57. Franciszek, „Kiedy milczenie staje się współwiną. Orędzie na Światowy Dzień Migranta i Uchodźcy 2016 roku" (12 września 2015 r.), L'Osservatore Romano (wyd. pol.) 36 (2015) nr 10, 10-12.

Franciszek, „Rewolucja czułości. Homilia w sanktuarium Matki Miłosierdzia w El Cobre" (22 września 2015 r.), L'Osservatore Romano (wyd. pol.) 36 (2015) nr 10, 24-25.

Franciszek, „Potrzebna jest rodzina. Homilia na święto Świętej Rodziny: Jezusa, Maryi i Józefa" (27 grudnia 2015 r.), L'Osservatore Romano (wyd. pol.) 37 (2016) nr 1, 15-16.

Franciszek, „Jedynym przywilejem jest nie mieć przywilejów. Rozważanie przed modlitwą Anioł Pański" 31 stycznia 2016 r.), L’Osservatore Romano (wyd. pol.) 37 (2016) nr 2, 43.

Franciszek, „Z proroczą odwagą. Przemówienie do meksykańskich biskupów podczas spotkania w katedrze w stolicy Meksyku" (13 lutego 2016 r.), L'Osservatore Romano (wyd. pol.) 37 (2016) nr 3-4, 21-27.

Franciszek, „Bóg przychodzi otrzeć łzy z naszego oblicza. Rozważanie podczas czuwania modlitewnego dla wszystkich, którzy potrzebują pocieszenia" (5 maja 2016 r.), L'Osservatore Romano (wyd. pol.) 37 (2016) nr 5, 26-27.

Franciszek, „«Nieletni migranci, bezbronni i bez głosu». Orędzie na Światowy Dzień Migranta i Uchodźcy 2017 roku" (8 września 2016 r.), L'Osservatore Romano (wyd. pol.) 36 (2016) nr 11, 4-6.

Franciszek, „Pod płaszczem Matki jesteśmy bezpieczni. Homilia w Domu Świętej Marty" (15 września 2016 r.), L'Osservatore Romano (wyd. pol.) 37 (2016) nr 9, 26.

Franciszek, „Czy umiemy mówić dziękuję? Homilia na zakończenie Jubileuszu Maryjnego" (9 października 2016 r.), L'Osservatore Romano (wyd. pol.) 37 (2016) nr 10, 5-6. 
Franciszek, „Misericordia et misera. List apostolski na zakończenie Nadzwyczajnego Jubileuszu Miłosierdzia" (20 listopada 2016 r.), L'Osservatore Romano (wyd. pol.) 37 (2016), nr 12, 4-12.

Franciszek, „Tam, gdzie jest matka, jest zawsze smak domu. Homilia na liturgiczne wspomnienie Najświętszej Maryi Panny z Guadalupe" (12 grudnia 2016 r.), L'Osservatore Romano (wyd. pol.) 38 (2017) nr 1, 23-25.

Franciszek, „Jak w Efezie. Homilia na uroczystość Świętej Bożej Rodzicielki Maryi”' (1 stycznia 2017 r.), L'Osservatore Romano (wyd. pol.) 38 (2017) nr $1,13-15$.

Franciszek, „Przyjmować, chronić, promować i integrować. Przemówienie do uczestników VI Międzynarodowego Forum «migracje i pokój»»" (21 lutego 2017 r.), L'Osservatore Romano (wyd. pol. 38 (2017) nr 3-4, 20-23.

Franciszek, „Maryja stała. Katecheza wygłoszona podczas audiencji generalnej” (10 maja 2017 r.), L'Osservatore Romano (wyd. pol.) 38 (2017) nr 6-7, 29-30. Franciszek, ,Jak Maryja bądźmy znakiem miłosierdzia Boga. Przemówienie do wiernych zgromadzonych na czuwaniu modlitewnym w Fatimie" (12 maja 2017 r.), L'Osservatore Romano (wyd. pol.) 38 (2017) nr 5, 19-20.

Franciszek, „Przyjmowanie, chronienie, promocja i integracja imigrantów i uchodźców. Orędzie na Światowy Dzień Migranta i Uchodźcy 2018 roku" (15 sierpnia 2017 r.), L'Osservatore Romano (wyd. pol.) 38 (2017) nr 9, 4-7. Franciszek, „Kiedy Jezus mówi «niewiasta». Homilia w Domu Świętej Marty” (15 września 2017 r.), L’Osservatore Romano (wyd. pol.) 38 (2017) nr 10, 55. Franciszek, „Grzech postarza. Rozważanie przed modlitwą Anioł Pański” (8 grudnia 2017 r.), L'Osservatore Romano (wyd. pol.) 39 (2018) nr 1, 45.

Franciszek, „Nie gaśmy nadziei migrantów. Rozważanie przed modlitwą Anioł Pański" (1 stycznia 2018 r.), L'Osservatore Romano (wyd. pol.) 39 (2018) nr 1, 19-20.

Franciszek, „Przed żłóbkiem odkrywamy, że jesteśmy miłowani. Homilia na uroczystość Świętej Bożej Rodzicielki Maryi” (1 stycznia 2018 r.), L'Osservatore Romano (wyd. pol.) 39 (2018) nr 1, 18-19.

Franciszek, „Przezwyciężenie lęku pozwala wyjść na spotkanie bliźniego. Homilia na Światowy Dzień Migranta i Uchodźcy" (14 stycznia 2018 r.), L'Osservatore Romano (wyd. pol.) 39 (2018) nr 2, 44-45.

Franciszek, „Największą przeszkodą jest lęk. Orędzie na 33. Światowy Dzień Młodzieży" (11 lutego 2018 r.), L’Osservatore Romano (wyd. pol.) 39 (2018) nr 3-4, 4-7.

Franciszek, „Naszym zadaniem jest budowanie globalnej cywilizacji przymierza. Przemówienie do członków Ruchu «Focolari» w Loppiano" (10 maja 2018 r.), L'Osservatore Romano (wyd. pol.) 39 (2018) nr 6, 10-14.

Franciszek, „Solidarność jest jedyną odpowiedzią. Homilia dla migrantów” (6 lipca 2018 r.), L'Osservatore Romano (wyd. pol.) 39 (2018) nr 7, 38-39. 
Franciszek, „Trzeba przyjąć z miłością drugiego człowieka. Homilia przed sanktuarium maryjnym w Agłonie" (24 września 2018 r.), L'Osservatore Romano (wyd. pol.) 39 (2018) nr 10, 31-32.

Franciszek, „Wszystko może ten, kto ufa Bogu. Rozważanie przed modlitwą Anioł Pański" (8 grudnia 2018 r.), L'Osservatore Romano (wyd. pol.) 39 (2018) nr 12, 26-27.

Franciszek, „Matka Boża wnosi do Kościoła atmosferę czułości. Homilia na uroczystość Świętej Bożej Rodzicielki Maryi” (1 stycznia 2019 r.), L'Osservatore Romano (wyd. pol.) 40 (2019) nr 1, 19-21.

Franciszek, „Potrzeba odwagi, żeby powtórzyć «tak» Maryi. Przemówienie podczas czuwania z młodzieżą w Metro Park" (26 stycznia 2019 r.), L'Osservatore Romano (wyd. pol.) 40 (2019) nr 2, 26-30.

Franciszek, „Nie chodzi tylko o migrantów. Orędzie na Światowy Dzień Migranta i Uchodźcy" (27 maja 2019 r.), L'Osservatore Romano (wyd. pol.) 40 (2019) nr 7-8, 4-6.

Franciszek, „Umacniajcie kulturę spotkania. Homilia w bukaresztańskiej katedrze pw. św. Józefa" (31 maja 2019 r.), L'Osservatore Romano (wyd. pol.) 40 (2019) nr 7-8, 22-23.

Franciszek, „Łaska przemieniania uraz w nowe szanse jedności. Homilia w sanktuarium w Şumuleu Ciue" (1 czerwca 2019 r.), L'Osservatore Romano (wyd. pol.) 40 (2019) nr 7-8, 24-25.

Franciszek, „Uczeń Chrystusa jest wędrowcem, działa pospiesznie i zdecydowanie. Rozważanie przed modlitwą Anioł Pański” (30 czerwca 2019 r.), L'Osservatore Romano (wyd. pol.) 40 (2019) $\mathrm{nr}$ 7-8, 52-53.

Franciszek, „Ruch i zdumienie. Rozważanie przed modlitwą Anioł Pański” (2 lutego 2020 r.), L'Osservatore Romano (wyd. pol.) 41 (2020) nr 2-3, 32-33. Franciszek, „Matka Boża Bolesna - uczennica i matka. Homilia w Domu Świętej Marty" (3 kwietnia 2020 r.), L'Osservatore Romano (wyd. pol.) 41 (2020) nr 5, 38.

Franciszek, „Spotkanie z innym jest spotkaniem z Chrystusem. Homilia w 7. rocznicę wizyty na Lampedusie" (8 lipca 2020 r.), L'Osservatore Romano (wyd. pol.) 41 (2020) nr 9, 4-5.

Franciszek, „Droga braterstwa. Rozważanie przed modlitwą Anioł Pański” (2 sierpnia 2020 r.), L'Osservatore Romano (wyd. pol.) 41 (2020) nr 9, 21-22. Franciszek, ,Jedna z nas mieszka w niebie. Rozważanie przed modlitwą Anioł Pański" (15 sierpnia 2020 r.), L'Osservatore Romano (wyd. pol.) 41 (2020) nr 9, 24-25.

Franciszek, „Jak Jezus Chrystus zmuszeni do ucieczki. Orędzie na Światowy Dzień Migranta i Uchodźcy 2020 roku” (27 września 2020 r.), L'Osservatore Romano (wyd. pol.) 41 (2020) nr 6, 4-5.

Franciszek, Encyklika Fratelli tutti (3 października 2020 r.), Kraków 2020. Franciszek, Pozza M., Ave Maria, Studio perbene (tłum.), Niepokalanów 2018. 
Kasper, W., Papież Franciszek. Rewolucja czułości i miłości. Korzenie teologiczne i perspektywy duszpasterskie, tłum. K. Markiewicz, Warszawa 2015.

Komisja ds. Kultu Bożego i Dyscypliny Sakramentów Konferencji Episkopatu Polski, „Komunikat na temat nowych wezwań Litanii loretańskiej”, https:// opoka.news/w-sprawie-wezwan-litanii-loretańskiej (dostęp 28.01.2021).

Konferencja Episkopatu Polski, „Biskupi zatwierdzili brzmienie trzech nowych wezwań «Litanii loretańskiej»", https://episkopat.pl/biskupi-zatwierdzili-brzmienie-trzech-nowych-wezwan-litanii-loretanskiej (dostęp 16.12.2020).

Kongregacja ds. Kultu Bożego i Dyscypliny Sakramentów, „Litterae circulares ad praesides Conferentiarum Episcoparum de invocationibus «Mater misericordiae», «Mater spei» et «Solacium migrantium» in Litanias Lauretanas inserendis" (20 decembre 2020), https://press.vatican.va/content/salastampa/ it/bollettino/pubblico/2020/06/20/0350/00805.html\#la (dostęp 16.12.2020).

Kućko, W., „Braterstwo w nauczaniu papieża Franciszka”, Collectanea Theologica 90 (2020) nr 3, 123-162.

Kudasiewicz, J., Matka Odkupiciela, Kielce 1991.

Kumala, J., „Maryja znakiem nadziei i pociechy”, Salvatoris Mater 2 (2000) nr 4, 59-106.

Okafor, I., „Der verzweifelte Migrant. Eine theologische Kritik der Flüchtlingskrise im Licht von Papst Franziskus Appel für brüderliche Solidarität”, w: K. Appel, J.H. Deibl (red.), Barmherzigkeit und Liebe. Das theologische Programm von Papst Franziskus, Freiburg am Breisgau 2016, 289-304.

Samiec, Ł., „Maryja i «preferencyjna opcja na rzecz ubogich». Projekt soteriologii profetycznej w świetle teologii latynoamerykańskiej”, Kraków 2019.

Schönborn, Ch., „Maria - Herz der Theologie - Theologie des Herzens”, w: J. Kreiml, V. Neumann (red.), 100 Jahre Patrona Bavariae. Marienverehrung in Bayern, Regensburg 2017, 111-133.

Vantini, L., „Stabat Mater - Ethik der Sorge in Evangelii gaudium. Mit den Augen der Frau unter dem Kreuz, w: K. Appel, J.H. Deibl (red.), Barmherzigkeit und zärtliche Liebe. Das theologische Programm von Papst Franziskus, Freiburg im Breisgau, 323-335.

Warchoł, P., „Maryja w nauczaniu papieża Franciszka” Salvatoris Mater 19 (2017) nr 1-4, 216-237.

Wojtczak, A., „Matka i Królowa. Ku integralnemu i pogłębionemu rozumieniu tytułów maryjnych", Poznań 2009.

Wojtczak, A., Czułe oblicze Matki. Przewodnie motywy mariologii papieża Franciszka, Poznań 2019.

Wojtczak, A., „Marian Inspirations for the Culture of Encounter according to Pope Francis”, Poznańskie Studia Teologiczne 36 (2020), 111-135. 